\section{Notaire}

Vol. 2 No. 3, Oktober 2019
e-ISSN: 2655-9404

DOI: $10.20473 /$ ntr.v2i3.16227

Article history: Submitted 4 September 2019 ; Accepted 11 September 2019; Available online 1 October 2019.

\title{
Kedudukan Persekutuan Komanditer (Commanditaire Venootschap) Sebagai Corporate Guarantee
}

\author{
Ida Bagus Abhimantara \\ ida.bagus.abhimantara-2016@fh.unair.ac.id \\ Universitas Airlangga
}

\begin{abstract}
In this paper the author presents a legal perspective in an individual guarantee agency or borgtocht. Vennootschap Commanditaire (CV) which is positioned as a business entity that is not a legal entity taking the position as a corporate guarantee in the additional agreement of the main agreement, it is necessary to examine the legality and authority of the business entity to take legal action as a guarantor of Debtor debt. Issues discussed in this paper regarding the position of the CV as a corporate guarantee in the guarantor agreement and the validity of the $C V$ to be the guarantor in $a$ coverage agreement. The legal issues raised in this paper conclude that a $C V$ which is a non-legal entity business entity cannot be positioned as a corporate guarantee or borgtocht because in the individual guarantee provisions in Article 1820 Burgerlijk Wetboek (BW) that can be a guarantor are legal subjects both legal entities (recht persoon) nor individuals (naturlijk persoon) and CV as business entities do not have the authority to act (bevoegheid) and the said guarantor agreement can be canceled (vernietigbaar) because it does not meet the subjective elements in Article $1320 \mathrm{BW}$. Keywords: Limited Partnership; Company Guarantee; Borgtocht.
\end{abstract}

\begin{abstract}
Abstrak
Dalam tulisan ini penulis menyajikan suatu perspektif hukum dalam lembaga jaminan perorangan atau disebut sebagai borgtocht. Commanditaire vennootschap (CV) yang berposisi sebagai badan usaha yang tidak berbadan hukum mengambil posisi sebagai corporate guarantee dalam perjanjian accesoir dari perjanjian pokoknya, maka perlu dikaji keabsahan dan kewenangan badan usaha tersebut untuk melakukan tindakan hukum sebagai penanggung utang Debitor. Permasalahan yang dibahas dalam tulisan ini mengenai kedudukan $\mathrm{CV}$ selaku corporate guarantee dalam perjanjian penanggungan dan keabsahan CV menjadi penanggung dalam suatu perjanjian penanggungan. Isuisu hukum yang dikemukakan dalam tulisan ini menyimpulkan bahwa CV yang merupakan badan usaha tidak berbadan hukum tidak dapat berposisi sebagai corporate guarantee atau borgtocht karena dalam ketentuan jaminan perorangan pada Pasal 1820 Burgerlijk Wetboek yang dapat menjadi penanggung adalah subjek hukum baik badan hukum (recht persoon) maupun orang perorangan (naturlijk persoon) dan CV sebagai badan usaha tidak memiliki kewenangan bertindak (bevoegheid) dan perjanjian penanggungan tersebut dapat dibatalkan (vernietigbaar) karena tidak memenuhi unsur subyektif dalam Pasal 1320 BW.
\end{abstract}

Kata Kunci: Persekutuan Komanditer; Jaminan Perusahaan; Borgtocht.

\section{Pendahuluan}

Dalam menjalankan roda perekonomian di masyarakat, aturan-aturan hukum tentunya harus dapat mengakomodir konsep-konsep yang hidup di dalam masyarakat itu sendiri, untuk mengakomodir hal tersebut terbentuklah suatu konsep badan usaha yang lazim disebut sebagai perusahaan. 
Ada tiga jenis badan usaha yang telah kita kenal, yang pertama adalah perusahaan perorangan di mana perusahaan ini didirikan oleh satu orang saja, perusahaan perseorangan ini biasa disebut Perusahaan Dagang (PD) atau Usaha Dagang (UD). Yang kedua adalah badan usaha yang berbentuk persekutuan, biasanya berupa Persekutuan Perdata (Maatschap), Persekutuan Firma (Firm), dan Persekutuan Komanditer (Commanditaire Vennootschap). Jenis badan usaha yang terakhir adalah badan usaha yang yang berbadan hukum, yakni berbentuk Perseroan Terbatas (PT), Koperasi, Perusahaan Umum (Perum), dan Perusahaan Daerah.

Pada dasarnya, sebagian besar negara mengenal tiga bentuk organisasi perusahaan, yaitu perusahaan perseorangan (sole proprietorship or sole trader), perusahaan persekutuan (parnertship) dan perusahaan perseroan (company or corporation). ${ }^{1}$

Salah satu badan usaha yang berposisi bukan sebagai badan hukum yaitu Persekutuan Komanditer (selanjutnya disebut CV), CV adalah perseroan yang terbentuk dengan cara meminjamkan uang, yang didirikan oleh seseorang atau beberapa pesero yang bertanggung gugat secara tanggung renteng dan satu orang pesero atau lebih yang bertindak sebagai pemberi pinjaman uang. ${ }^{2}$ Di dalam organisasi CV terdapat satu atau lebih sekutu komplementer dan sekutu komanditer, sekutu komplementer berhak bertindak untuk dan atas nama bersama semua sekutu serta bertanggung gugat terhadap pihak ketiga secara tanggung renteng sampai harta pribadi, sedangkan sekutu komanditer atau disebut juga sebagai sekutu pasif adalah sekutu yang memasukan modal baik berupa uang ataupun benda ke dalam perseroan (inbreng) dan berhak atas keuntungan perseroan namun dalam hal tanggung gugat terhadap pihak ketiga, sekutu komanditer hanya bertanggung gugat sampai harta yang dimasukan ke dalam perseroan saja.

Keberadaan Persekutuan Komanditer dalam lalu lintas bisnis telah dikenal masyarakat, terutama masyarakat pengusaha, sebagai salah satu bentuk badan usaha. Dasar pengaturan CV dalam Kitab Undang-Undang Hukum Dagang tidak diatur secara khusus/tersendiri sebagaimana persekutuan firma dan persekutuan perdata

\footnotetext{
1 Robert W. Emerson, Business Law (4 th, Barron's Educational Series, Inc 2004).[296].

2 Pasal 19 Kitab Undang-Undang Hukum Dagang.
} 
(Maatschap), namun beberapa kalangan ahli hukum berpendapat bahwa bagi CV dapat diberlakukan terhadap pasal-pasal mengenai persekutuan firma maupun persekutuan perdata. Ketentuan CV terdapat pada pasal 19, 20, 21 dan pasal 32 KUHD. ${ }^{3}$ Ketentuan Pasal 19 sampai dengan Pasal 21 KUHD yang mengatur tentang Firma jika dikaji lebih jauh, jelaslah bahwa CV adalah Firma dengan bentuk khusus. Kekhususannya itu terletak pada eksistensi sekutu komanditer yang tidak ada pada Firma. Firma hanya mempunyai sekutu aktif yang disebut firmant, sedangkan pada CV selain ada sekutu aktif juga ada sekutu komanditer atau sekutu pasif (sleeping partner). ${ }^{4}$ Bentuk usaha $\mathrm{CV}$ ada 3 (tiga) macam yaitu: ${ }^{5}$

a. Persekutuan komanditer diam-diam, yaitu persekutuan komanditer yang belum menyatakan dirinya dengan terang-terangan kepada pihak ketiga sebagai persekutuan komanditer. Bertindak keluar perusahaan, persekutuan itu masih menyatakan dirinya sebagai persekutuan firma, tetapi bertindak ke dalam perusahaan, persekutuan itu sudah menjadi persekutuan komanditer.

b. Persekutuan komanditer terang-terangan, yaitu persekutuan komanditer yang dengan terang-terangan menyatakan dirinya sebagai persekutuan komanditer kepada pihak ketiga.

c. Persekutuan komanditer dengan saham, yaitu persekutuan komanditer terangterangan yang modalnya terdiri dari saham-saham. Persekutuan bentuk ini sama sekali tidak diatur dalam KUHD.

Sumber modal CV dalam menjalankan usahanya dapat ditinjau dari segi internal maupun eksternal CV itu sendiri. Sumber modal internal yaitu dari pemasukan modal (inbreng) para pengurus dan sumber modal eksternal misalnya melalui pinjaman dari lembaga perbankan maupun lembaga non perbankan dengan jaminan tertentu. ${ }^{6}$

\footnotetext{
3 I.G. Rai Widjaya, Hukum Perusahaan (Undang-Undang Dan Peraturan Pelaksana Undang-Undang Di Bidang Usaha) (Mega Poin, Divisi dari Kesain Blanc 2005).[1].

4 Soekardono, Hukum Dagang Indonesia (Jilid 1 Ba, (Rajawali Pers 1991).[102].

5 H.M.N. Purwositjipto, Pengertian Pokok Hukum Dagang Indonesia 2: Bentuk- Bentuk Perusahaan (Djambatan 2005).[76].

${ }^{6}$ Hexxy Nurbaiti Ariesi, 'Tanggung Jawab Pengurus Persekutuan Komanditer Dalam Keadaan Pailit' (Universitas Diponegoro 2007).[6].
} 
Untuk menjalankan suatu usaha biasanya seseorang akan berusaha untuk menambah modal kerja sebagai proses membesarkan usaha yang ditekuni, salah satu cara agar mendapatkan modal kerja adalah dengan cara mengajukan fasilitas pinjaman kepada Bank, dari konstruksi tersebut lahirlah perjanjian kredit sebagai perjanjian pokok yang diikuti oleh perjanjian accesoir yang biasanya berupa lembaga jaminan hak tanggungan, fidusia, hipotek atau gadai, tetapi tidak menutup kemungkinan Bank selaku kreditor menginginkan jaminan tambahan berupa jaminan perorangan atau dalam hal ini sebagai corporate guarantee.

Lembaga corporate guarantee sebagai salah satu bentuk lembaga jaminan perorangan, pada dasarnya adalah merupakan perjanjian penanggungan utang (borgtocht), sebagaimana diatur dalam Buku III Burgerlijk Wetboek (selanjutnya disebut BW), Pasal 1820 BW sampai dengan Pasal 1850 BW. Subekti mengartikan jaminan perorangan adalah suatu perjanjian antara seorang berpiutang (kreditur) dengan seorang ketiga, yang menjamin dipenuhinya kewajiban-kewajiban si berhutang (debitur). Ia bahkan dapat diadakan di luar (tanpa) sepengetahuan si berhutang tersebut. ${ }^{7}$ Bahwa maksud adanya jaminan ini adalah untuk pemenuhan kewajiban si berhutang, yang dijamin pemenuhannya seluruhnya atau sampai suatu bagian tertentu, harta benda si penanggung (penjamin) dapat disita dan dilelang menurut ketentuan perihal pelaksanaan eksekusi putusan pengadilan. ${ }^{8}$

Tujuan dan isi perjanjian penanggungan ini ialah memberikan jaminan untuk dipenuhinya perutangan dalam perjanjian pokok sebagaimana disebutkan dalam Pasal $1821 \mathrm{BW}$ yang menyatakan tiada penanggungan jika tidak ada suatu perikatan pokok yang sah. ${ }^{9}$ Hal ini sesuai dengan sifat penanggungan sebagai jenis jaminan yang bersifat accesoir, sedangkan pengertian lembaga corporate guarantee sendiri adalah merupakan suatu jaminan berupa janji atau pernyataan

\footnotetext{
7 R. Subekti, Jaminan-Jaminan Untuk Pemberian Kredit Menurut Hukum Indonesia (Citra Aditya Bakti 1989). [15].

8 Diah Handayani, 'Kedudukan Corporate Guarantor Sebagai Pihak Penjamin Debitur Utama Dalam Proses Kepailitan' [2016] Jurnal Magister Kenotariatan Fakultas Hukum Universitas Sumatera Utara.[3].

9 Pasal 1821 Burgerlijk Wetboek.
} 
kesanggupan yang diberikan oleh perusahaan penanggung untuk memenuhi kewajiban debitor, manakala debitor sendiri wanprestasi. Jadi dalam lembaga corporate guarantee, setidaknya terdapat tiga pihak yang saling terkait satu sama lain yaitu pihak kreditor, debitor dan pihak ketiga (perusahaan) yang bertindak sebagai penanggung (borg, guarantor).

Jaminan perorangan tersebut terbagi atas dua jenis, yaitu jaminan yang dilakukan oleh pribadi (personal guarantee) dan pemberian garansi yang dilakukan oleh badan hukum (corporate guarantee). Pada dasarnya keduanya memiliki prinsip yang sama dimana hak dan kewajiban yang dimiliki pemberi garansi (penjamin) pada kedua jenis penanggungan tersebut identik, hanya saja subjek pelakunya berbeda. ${ }^{10}$

Corporate Guarantee merupakan jenis lembaga jaminan yang lahir karena ditentukan oleh undang-undang dan jaminan yang lahir karena perjanjian. Jaminan yang ditentukan oleh Undang-Undang ialah jaminan yang adanya ditunjuk oleh Undang-Undang tanpa adanya perjanjian dari para pihak yaitu misalnya adanya ketentuan undag-undang yang menentukan bahwa semua harta benda debitur baik benda bergerak maupun benda tetap, baik benda-benda yang sudah ada maupun yang masih akan ada menjadi jaminan bagi seluruh perutanganya. Berarti bahwa kreditur dapat melaksanakan haknya terhadap semua benda debitur, kecuali benda-benda yang dikecualikan oleh UndangUndang (Pasal $1131 \mathrm{BW}){ }^{11}$

Lembaga jaminan perusahaan yang lazim digunakan di masyarakat pada dasarnya adalah lembaga jaminan pribadi atau borgtocht yang diatur dalam Pasal $1820 \mathrm{BW}$, maka dari itu perlu kita tinjau bagaimana kedudukan CV sebagai badan usaha bukan badan hukum sebagai corporate guarantee ditinjau dari peraturan perundang-undangan di Indonesia saat ini.

${ }^{10}$ Adrian Sutedi, Hukum Kepailitan (Ghalia Indonesia 2009).[151].

${ }^{11}$ Sri Soedewi Masjchoen Sofwan, Hukum Jaminan Di Indonesia Pokok-Pokok Hukum Jaminan Dan Jaminan Perorangan (Badan Pembinaan Hukum Nasional Departemen Kehakiman 1980).[43]. 


\section{Kedudukan Commanditaire Vennootschap Sebagai Corporate Guarantee}

Institusi perbankan memegang peranan penting dalam roda perekonomian suatu negara, pemberian kredit terhadap masyarakat umum turut membantu geliat ekonomi suatu negara. Bank sebagai penyalur kredit tentu menginginkan perlindungan ekstra untuk memperlancar jalannya transaksi bisnis yang dilakukan antara kreditor dengan debitor, adapun perangkat yang dapat dimanfaatkan Bank sebagai pihak yang mengucurkan dana pinjaman, terangkum dalam norma-norma hukum jaminan.

Hubungan hukum antara Bank selaku kreditor dan nasabah peminjam selaku debitor akan diikat dengan perjanjian kredit. Sesuai hakekatnya perjanjian kredit ini bila dikaitkan dengan Pasal 1319 BW tergolong sebagai perjanjian tak bernama mengingat tidak diaturnya ketentuan perjanjian kredit di dalam BW. Berlandas pada Pasal 1319 BW itu pulalah maka perjanjian kredit ini terkwalifikasi dalam perjanjian obligatoir sehingga melahirkan hak tagih yang tergolong sebagai hak perorangan atau hak pribadi. ${ }^{12}$ Lahirnya perjanjian kredit membuat Bank demi hukum berposisi sebagai kreditor konkuren yang hanya dibentengi konstruksi jaminan umum sebagaimana tertuang dalam Pasal 1131 BW, untuk lebih memastikan kelancaran jalannya perjanjian kredit tersebut biasanya Bank akan menambahkan perjanjian accesoirnya yang disebut sebagai perjanjian jaminan, di mana terdapat dua jenis perjanjian jaminan yaitu perjanjian jaminan kebendaan dan perjanjian jaminan perorangan.

Dalam hal ini corporate guarantee pada dasarnya adalah jaminan perorangan sebagaimana yang dimaksud dalam Pasal 1820 BW, perjanjian jaminan perorangan terjadi kalau ada pihak ketiga yang bersedia menjadi penanggung (borg) atas utangnya debitor dan atas dasar sepakat kreditor lalu dirakit dalam suatu perjanjian yang dikenal dengan nama perjanjian perorangan. ${ }^{13}$ Pasal $1820 \mathrm{BW}$ pada intinya menyatakan bahwa penanggungan adalah suatu perjanjian di mana seorang pihak ketiga demi kepentingan kreditor bersedia mengikatkan dirinya untuk melunasi utang debitor bila wanprestasi, dari ketentuan tersebut tampak jelas perjanjian penanggungan tersebut berposisi

\footnotetext{
${ }_{12}$ Moch. Isnaeni, Pijar Pendar Hukum Perdata (PT Revka Petra Media 2016).[36].

${ }^{13}$ Moch. Isnaeni, Pengantar Hukum Jaminan Kebendaan (PT Revka Petra Media 2016).[110].
} 
sebagai perjanjian accesoir yang eksistensinya bergantung pada perjanjian pokok. Maksud dari diadakannya jaminan perorangan adalah untuk pemenuhan kewajiban si berutang, yang dijamin pemenuhannya seluruhnya atau sampai suatu bagian tertentu, harta benda si penanggung (penjamin) dapat disita dan dilelang menurut ketentuan perihal pelaksanaan eksekusi putusan pengadilan. ${ }^{14}$

Jika dilihat dari ketentuan-ketentuan dalam BW, sifat-sifat borgtocht diantaranya melahirkan hak perorangan/hak pribadi sehingga kedudukan Kreditor yang dijamin borgtocht berkedudukan sebagai kreditor konkuren, besarnya jaminan tidak melebihi syarat-syarat yang lebih berat dari perikatan pokok sebagaimana diatur pada Pasal $1822 \mathrm{BW},{ }^{15}$ penjamin baru membayar utang jika debitor tidak memiliki kemampuan lagi, karena sifatnya cadangan maka undang-undang memberikan hakhak istimewa kepada seorang penjamin, yaitu sebagaimana diatur pada Pasal 1832, 1836, 1837, 1847, 1848, 1849, 1850 BW. ${ }^{16}$ Dalam praktik hak istimewa yang dimiliki oleh penjamin oleh Bank diminta untuk melepaskannya, sehingga membuka peluang Bank untuk dapat menuntut langsung kepada penjamin untuk melunasi utang debitor tanpa harus menjual harta benda milik debitor terlebih dahulu. ${ }^{17}$

Terdapat perlindungan yang diberikan oleh Pasal 1831 dan 1832 BW kepada Corporate Guarantor dalam praktiknya dianggap memberatkan kreditor. Perlindungan tersebut mengakibatkan kreditor terhalang untuk melaksanakan haknya sehingga diperlukan janji-janji khusus untuk mengesampingkan hak istimewa penjamin sebagaimana diatur dalam BW, seperti:

a. Janji agar penanggung melepaskan haknya untuk menuntut penjualan harta benda debitur lebih dahulu;

Sebagai Penjamin, Corporate Guarantor memiliki hak istimewa bahwa Corporate Guarantor tidak diwajibkan untuk melunasi kewajiban debitor kepada kreditor sebelum harta kekayaan debitor yang cidera janji tersebut,

14 R. Subekti, Jaminan-Jaminan Untuk Pemberian Kredit Termasuk Hak Tanggungan Menurut Hukum Indonesia (Citra Aditya Bakti 1996).[17].

${ }_{15}$ Pasal 1822 Burgirlijk Wetboek.

16 Sutarno, Aspek-Aspek Hukum Perkreditan (Alfabeta 2004).[238-241].

17 ibid. 
yang ditunjuk oleh penjamin, telah disita dan dijual, dan hasil penjualan harta kekayaan debitor tidak mencukupi untuk memenuhi kewajiban debitor kepada kreditor. Oleh karena itu, Corporate Guarantor hanya akan melunasi sisa kewajiban debitor yang belum dipenuhinya kepada kreditor. ${ }^{18}$

b. Janji agar penjamin melepaskan haknya untuk membagi-bagi hutang (voorrechtvan schuldsplitsing);

Hak untuk membagi hutang ini terdapat pada penjamin yang penjaminannya lebih dari satu orang penjamin terhadap seorang debitor. Maka para penjamin masing-masing dapat memajukan hak untuk membagi debitor-debitor tadi diantara para penjamin. Sehingga utang debitor yang mereka jamin, dibagidibagi diantara mereka masing-masing. Apabila Corporate Guarantor melepaskan hak istimewanya maka Corporate Guarantor bertanggung jawab untuk menyelesaikan seluruh kewajiban debitur. Pelepasan hak istimewa untuk membagi hutang tersebut juga mengakibatkan kreditur dapat menuntut ahli waris Penjamin untuk pemenuhan seluruh piutangnya dan tidak dapat dibagi-bagi antara si ahli waris. ${ }^{19}$

c. Janji agar Penjamin melepaskan haknya untuk meminta kepada kreditor untuk diberhentikan atau dibebaskan dari kedudukannya sebagai seorang penjamin/guarantor jika ada alasan untuk itu. Alasan yang bisa digunakan sebagai dasar hukum meminta dibebaskan dari kedudukan seorang penjamin ialah kemungkinan penjamin tidak dapat menggunakan hak-hak subrogasi. Hak subrogasi timbul setelah penjamin/guarantor membayar atas utang debitor. Hak subrogasi tidak dapat dilaksanakan karena penjamin telah meneliti bahwa jaminan seperti hak tanggungan, hipotik, fiducia, dan lainnya yang menjamin utang tersebut telah hapus atau tidak ada lagi. Tidak adanya jaminan hipotik, hak tanggungan dikarenakan kreditor membiarkan debitor menjual atau menghilangkan jaminan. Dengan kata lain kreditor tidak mengamankan jaminan-jaminan atas utang debitor itu sehingga bila penjamin/

\footnotetext{
${ }^{18}$ Diah Handayani (n 8).Op.Cit.[7].

19 ibid.
} 
guarantor membayar utang debitor, penjamin/guarantor yang demi hukum menggantikan hak kreditor (subrogasi) tidak memperoleh jaminan hipotik, hak tanggungan dan garansi/jaminan lainnya. ${ }^{20}$

d. Janji agar penanggungan tetap, sah, tidak peduli apakah penanggung bersama ikut terikat. Dengan kata lain "lawfull" sebagaimana yang diutarakan Aristoteles dengan maksud hukum tidak boleh dilanggar dan aturan hukum harus diikuti menunjukkan bahwa segala ketentuan sebagaimana yang diatur dalam perjanjian pemberian jaminan harus lah diikuti karena merupakan hukum yang harus ditegakkan. ${ }^{21}$

Undang-undang mensyaratkan penjamin (borg) harus cakap untuk mengikatkan dirinya, cukup mampu memenuhi perikatannya dan berdomisili di wilayah Indonesia. ${ }^{22}$

Persekutuan Komanditer menurut Pasal 1 angka 1 Permenkumham Nomor 17 tahun 2018 tentang Pendaftaran Persekutuan Komanditer, Persekutuan Firma, dan Persekutuan Perdata menyatakan bahwa CV adalah persekutuan yang didirikan oleh satu atau lebih sekutu komanditer dengan satu atau lebih sekutu komplementer, untuk menjalankan usaha secara terus menerus. ${ }^{23} \mathrm{CV}$ seringkali disebut sebagai firma khusus karena di dalam $\mathrm{CV}$ terdapat pesero komanditer yang bertanggung gugat hanya sebatas modal yang disetor ke dalam perusahaan sedangkan pesero komplementer bertanggung gugat terhadap seluruh harta kekayaan pribadinya. Selain ciri tersebut, yang membedakan CV dengan perseroan terbatas adalah status badan hukum yang tidak dimiliki oleh CV walaupun kedua perusahaan digolongkan sebagai badan usaha. Perbedann status tersebut tentu berimplikasi menjadikan CV bukanlah sebagai subjek hukum dan tidak dapat bertindak sendiri dalam melakukan tindakan hukum karena tidak dapat digolongkan sebagai recht persoon.

Dilihat dari pembahasan di atas, bahwa Comanditaire Vennootschap yang

${ }^{20}$ ibid.[9].

21 Sri Soedewi Masjchoen Sofwan, Hukum Jaminan Di Indonesia Pokok-Pokok Hukum Jaminan Dan Jaminan Perorangan (Liberti Offset 1980).[97-98].

${ }_{22}$ Pasal 1827 Burgirlijk Wetboek.

${ }^{23}$ Pasal 1 angka 1 Permenkumham Nomor 17 tahun 2018. 
merupakan badan usaha tidak berbadan hukum tidak dapat berposisi sebagai corporate guarantee atau borgtocht karena dalam ketentuan jaminan perorangan pada Pasal 1820 BW yang dapat menjadi penanggung adalah subjek hukum baik badan hukum (recht persoon) maupun orang perorangan (naturlijk persoon).

\section{Keabsahan Commanditaire Vennootschap Yang Menjadi Corporate Guarantee Dalam Perjanjian Penanggungan}

Karakteristik dari suatu badan hukum biasanya terdapat pemisahan harta pemilik dengan harta kekayaan badan tersebut, akibat dari pemisahan harta tersebut badan usaha yang berbadan hukum dapat turut serta melakukan tindakan hukum layaknya naturlijk persoon sehingga pemilik suatu badan usaha berbadan hukum hanya bertanggung gugat sebatas harta yang dimasukan ke dalam perseroan. Saat ini badan usaha yang berbadan hukum terdiri dari Perseroan Terbatas, Yayasan dan Koperasi. Persekutuan komanditer tidak dapat disebut sebagai subjek hukum recht persoon dalam konstelasi hukum di Indonesia, hal tersebut tentu membatasi kewenangan $\mathrm{CV}$ untuk melakukan tindakan hukum layaknya badan usaha yang telah berbadan hukum.

Dalam hal $\mathrm{CV}$ dengan Bank telah membuat perjanjian penanggungan dan sepakat mengikatkan diri maka perjanjian tersebut berlaku sebagai undang-undang bagi para pihak sesuai dengan asas pacta sunt servanda yang termaktub dalam ketentuan Pasal 1338 BW. Keabsahan suatu perjanjian yang dibuat tidak terkecuali pada perjanjian penanggungan juga harus memperhatikan ketentuan-ketentuan syarat sahnya perjanjian yang diatur dalam Pasal $1320 \mathrm{BW}$, perjanjian yang dibuat oleh para pihak tentu harus memenuhi persyaratan sahnya suatu perjanjian agar perjanjian tersebut tidak cacat hukum. Terkait dengan syarat sahnya perjanjian diatur dalam ketentuan Pasal 1320 BW yang meliputi; ${ }^{24}$

1. sepakat mereka yang mengikatkan dirinya;

2. kecakapan untuk membuat suatu perikatan;

3. suatu hal tertentu;

4. suatu causa yang diperbolehkan.

${ }^{24}$ Pasal 1320 Burgirlijk Wetboek. 
Syarat sepakat dan cakap dalam Pasal 1320 BW jelas berkait erat dengan diri "subyek hukum" yang berperaga selaku kontraktan, oleh sebab itulah kedua syarat tersebut dalam ranah kontrak digolongkan sebagai "unsur subyektif". ${ }^{25}$ Jika unsur subyektif tersebut tidak terpenuhi secara baik oleh para pihak maka akibatnya perjanjian yang dibuat akan berposisi dapat dibatalkan (vernietigbaar) bukan batal demi hukum (nietig). Syarat suatu hal tertentu dan suatu causa yang diperbolehkan digolongkan sebagai syarat objektif yang mana bila tidak terpenuhi maka suatu perjanjian tersebut berakibat batal demi hukum. ${ }^{26}$

Salah satu unsur kecakapan dalam Pasal 1320 BW ialah kewenangan hukum, yang berarti kewenangan untuk menjadi pendukung hak dan kewajiban di dalam hukum27, untuk mendukung hak dan kewajiban tersebut tentu hanya dapat dilaksanakan oleh subyek hukum itu sendiri. Kewenangan bertindak atau disebut sebagai bevoegheid ini berbeda dengan kecakapan bertindak atau bekwaamheid, dalam Pasal 1320 BW kita dapat menemukan unsur kecakapan yang harus dipenuhi sebagai syarat sahnya suatu perjanjian, mengenai kecakapan bertindak Burgerlijk Wetboek mesyaratkan usia minimal 21 Tahun atau telah kawin untuk dapat secara mandiri melakukan tindakan hukum (vide : Pasal $330 \mathrm{BW}$ ) atau pada usia 18 tahun jika kita merujuk Undang-Undang Nomor 1 tahun 1974 tentang Perkawinan, sedangkan wewenang (bevoegdheid) dideskripsikan sebagai kekuasaan hukum (rechtsmacht). Jadi dalam konsep hukum publik, wewenang berkaitan dengan kekuasaan. ${ }^{28}$

Jika CV sebagai badan usaha yang tidak berbadan hukum mengambil posisi sebagai corporate guarantee yang mana dalam Pasal 1820 BW hanya dapat dilakukan oleh subyek hukum baik recht persoon ataupun naturlijk persoon, akan berimplikasi terhadap perjanjian penanggungan tersebut, karena CV sebagai badan usaha tidak memiliki kewenangan bertindak (bevoegheid) dan perjanjian

\footnotetext{
${ }^{25}$ Moch. Isnaeni (n 12).Op.Cit.[131].

${ }^{26}$ Ida Bagus Abhimantara, 'Karakteristik Perjanjian Transplantasi Organ Tubuh Manusia Di Indonesia' (Universitas Airlangga 2018).[7].

${ }^{27}$ Paton G.W.A., Texbook of Jurisprudence (2 th, ClarendonPress 1951).[314].

${ }^{28}$ Philipus M. Hadjon, 'Tentang Wewenang' [1997] Yuridika.
} 
penanggungan tersebut dapat dibatalkan (vernietigbaar) karena tidak memenuhi unsur subyektif dalam Pasal 1320 BW.

\section{Kesimpulan}

Comanditaire Vennootschap yang merupakan badan usaha tidak berbadan hukum tidak dapat berposisi sebagai corporate guarantee atau borgtocht karena dalam ketentuan jaminan perorangan pada Pasal 1820 BW yang dapat menjadi penanggung adalah subjek hukum baik badan hukum (recht persoon) maupun orang perorangan (naturlijk persoon).

Comanditaire Vennootschap sebagai badan usaha yang tidak berbadan hukum mengambil posisi sebagai corporate guarantee yang mana dalam Pasal 1820 BW hanya dapat dilakukan oleh subyek hukum baik recht persoon ataupun naturlijk persoon akan berimplikasi terhadap perjanjian penanggungan tersebut, karena CV sebagai badan usaha tidak memiliki kewenangan bertindak (bevoegheid) dan perjanjian penanggungan tersebut dapat dibatalkan (vernietigbaar) karena tidak memenuhi unsur subyektif dalam Pasal 1320 BW.

\section{Daftar Bacaan}

\section{Buku}

Adrian Sutedi, Hukum Kepailitan (Ghalia Indonesia 2009).

H.M.N. Purwositjipto, Pengertian Pokok Hukum Dagang Indonesia 2: BentukBentuk Perusahaan (Djambatan 2005).

I.G. Rai Widjaya, Hukum Perusahaan (Undang-Undang Dan Peraturan Pelaksana Undang-Undang Di Bidang Usaha) (Mega Poin, Divisi dari Kesain Blanc 2005).

Moch. Isnaeni, Pengantar Hukum Jaminan Kebendaan (PT Revka Petra Media 2016).

—_, Pijar Pendar Hukum Perdata (PT Revka Petra Media 2016).

Paton G.W.A., Texbook of Jurisprudence (2 th, ClarendonPress 1951). 
R. Subekti, Jaminan-Jaminan Untuk Pemberian Kredit Menurut Hukum Indonesia (Citra Aditya Bakti 1989).

—_, Jaminan-Jaminan Untuk Pemberian Kredit Termasuk Hak Tanggungan Menurut Hukum Indonesia (Citra Aditya Bakti 1996).

Soekardono, Hukum Dagang Indonesia (Jilid 1 Ba, (Rajawali Pers 1991).

Sri Soedewi Masjchoen Sofwan, Hukum Jaminan Di Indonesia Pokok-Pokok Hukum Jaminan Dan Jaminan Perorangan (Liberti Offset 1980).

—-, Hukum Jaminan Di Indonesia Pokok-Pokok Hukum Jaminan Dan Jaminan Perorangan (Badan Pembinaan Hukum Nasional Departemen Kehakiman 1980).

Sutarno, Aspek-Aspek Hukum Perkreditan (Alfabeta 2004).

\section{Tesis}

Hexxy Nurbaiti Ariesi, ‘Tanggung Jawab Pengurus Persekutuan Komanditer Dalam Keadaan Pailit' (Universitas Diponegoro 2007).

Ida Bagus Abhimantara, 'Karakteristik Perjanjian Transplantasi Organ Tubuh Manusia Di Indonesia' (Universitas Airlangga 2018).

\section{Jurnal}

Diah Handayani, 'Kedudukan Corporate Guarantor Sebagai Pihak Penjamin Debitur Utama Dalam Proses Kepailitan' [2016] Jurnal Magister Kenotariatan Fakultas Hukum Universitas Sumatera Utara.

Philipus M. Hadjon, ‘Tentang Wewenang' [1997] Yuridika.

Robert W. Emerson, Business Law (4 th, Barron's Educational Series, Inc 2004).

\section{Perundang-undangan}

Burgerlijk Wetboek, diterjemahkan oleh Subekti, (PT Dian Rakyat, 2009).

Undang-Undang Nomor 1 Tahun 1974 Tentang Perkawinan, Lembaran Negara Nomor 1 Tahun 1974.

Permenkumham Nomor 17 tahun 2018 tentang Pendaftaran Persekutuan Komanditer, Persekutuan Firma, dan Persekutuan Perdata.

HOW TO CITE: Ida Bagus Abhimantara, 'Kedudukan Persekutuan Komanditer (Commanditaire Venootschap) Sebagai Corporate Guarantee' (2019) Vol. 2 No. 3 Notaire. 
--Halaman ini sengaja dibiarkan kosong-- 